\title{
STUDY OF THE IMPACT OF THE COVID-19 PANDEMIC ON RENTAL RELATIONS IN RUSSIA IN ORDER TO IMPROVE THE QUALITY OF ACCOUNTING EDUCATION
}

\author{
Ksenia Vladimirovna Senina ${ }^{1}$, Olga Nikolaevna Kalacheva ${ }^{2 *}$ \\ ${ }^{1}$ SD, Plekhanov Russian University of Economics, Russian Federation, kseniya- \\ senina@yandex.ru \\ ${ }^{2}$ Associate Prof., Plekhanov Russian University of Economics, Russian Federation, \\ olgaklchv@rambler.ru \\ ${ }^{*}$ Corresponding author
}

\begin{abstract}
At present, many Russian organizations face the problem of finding and attracting long-term investments to expand production, acquire modern equipment and introduce new technologies. According to statistics, more than half of the equipment of Russian organizations has been in use for more than 10 years. In a situation where investment credit opportunities are limited, leasing becomes one of the most accessible and effective means of financing development and productive renewal. The regulation of leasing during the 2020 pandemic saw a number of significant changes. The Government had amended its legislation on tenants and lessors, which had raised a number of questions on both sides and had been the subject of intense debate. In today's economic climate, with many companies suspended in the wake of the pandemic, leasing relationships are undergoing significant changes. This is why the study of specific and necessary aspects of economic relations, such as rents, should be of great importance in the education of accountants. Since any economic decision is made not only on the basis of certain defined criteria, but also has a subjective approach based on actual experience. It is therefore important to provide graduates of higher registration institutions with not only a theoretical basis for understanding the nature and types of leases, but also practical skills for their future professional activities. A study of the main innovations in the regulation of leases during the quarantine period will provide a better understanding of the main problems faced by tenants and lessors today. It was concluded that there was a possible impact of current events on all parties to the lease operations.
\end{abstract}

Keywords: lease, lessee, lessor, pandemic

\section{INTRODUCTION}

Due to the spread of coronavirus infection COVID-19, a number of restrictive measures were adopted in Russia, as well as in the rest of the world. Restrictive measures have had a significant negative impact on the functioning of most organizations in various sectors of the economy. The fall in consumer demand, combined with unchanged costs, has caused huge losses to Russian businesses. Companies operating in leased premises and buildings were also affected. It is clear that, in order to recover from the impact of the 
pandemic, current professionals must possess a range of theoretical and practical skills and knowledge, including in-depth knowledge in the area of leasing. The aim of the study is to study the impact of government restrictive measures in Russia related to the pandemic on tenants and landlords. Analysis of changes in the regulation of leases and their consequences, and determination of the role and importance of training in the accounting of leases in the current crisis. The objectives of the study are to study and analyses the current situation in the commercial real estate market; Disclosure of the most significant legislative changes introduced in connection with the pandemic relating to leasing relationships, their professional evaluation from the perspective of influencing lessors and tenants; Assessment of the importance of improving the theoretical and practical knowledge of leasing professionals in the prevailing conditions.

\section{LITERATURE REVIEW}

The benefits of leasing are indisputable, especially for those organizations that are severely constrained in terms of financial resources to provide the production process with the necessary equipment and buildings (Chun, 2003; Yoshida, 2016). First of all, it concerns small and medium-sized businesses (Wang, 2016; Bhaird C.M., 2010; Avvakumova, 2020) Leasing is seen by scholars and practitioners as an alternative to borrowing, with obvious advantages in terms of both taxation and organizational form, and efficiency. (Krahnen, 1987; Zhang, 2018). Leasing relationships, from an economic point of view, increase the availability of capital, operational efficiency, and ultimately improve performance and potential growth. (Zhang, 2018, Mayes, 1988). Most researchers hold the view that conditionally, the entire analytically analyzed lease period in a pandemic can be divided into two parts: the crisis period and the recovery period (Martin, 2020). The main task of leading practitioners and academics is to study and identify possible effective ways of stabilizing national economies in specific directions. The problems of conceptual models of accounting for leases were raised ten years before the IFRS Board and the Financial Accounting Standards Board started to implement major leasing projects. (Peprníčková M., 2018; Morozova, 2020). The current rules for the accounting of leases have been defined and finalized by the Board of Directors at IFRS 16, which meets the Russian standard for the accounting of leases in all material aspects.

\section{THEORETICAL BACKGROUND}

In the process of studying the impact of the pandemic on rent relations in Russia, with a view to improving the quality of accounting education, first of all, legal and regulatory acts concerning measures to support business in the context of the pandemic were examined, namely innovations, concerning the support of tenants and lessors. The main legal and regulatory act to support tenants and landlords during the pandemic period is the Federal Law of 01.04.2020, 98-FL «On amendments to individual legislative acts of the Russian Federation on the issues of prevention and elimination of emergency situations». The Law introduces various measures to deal with the spread of coronavirus infection. One such measure is to support organizations and individual entrepreneurs that have been affected by the pandemic and are therefore unable to pay rent. In particular, these tenants are subject to deferred rental charges.

In Resolution of the Government of the English Federation of 03.04.2020, N 439 "On the establishment requirements for the conditions and deadlines for the postponement of rent of rent under lease agreements of immovable property" It is stated that a delay in rent is granted in respect of immovable property in State, municipal or private ownership, with the exception of residential premises (para.2). In order to obtain a deferral, a number of requirements listed in paragraph. 1 of the Requirements must be met. First, the activities of the tenant should be included in the list of industries most affected by the pandemic. If the activities of the lessee are not included in this list, the lessor has the right to refuse to defer the activities of the lessee. Second, the lease must be concluded prior to the establishment of a state of emergency (Requirements, para.1). The Decree of 03.04.2020 439 «On the Setting of Conditions and Deadlines for the Postponement of Payment of Rent under Real Estate Leases» sets detailed requirements for the terms and terms of the postponement of rent. The Federal Law 98-FL also provides for the possibility for the lessee to claim rent reduction for the year 2020 due to the impossibility of using the property.

Our research was also based on information sources in the field of accounting education. One of the sources for the study was an analysis of a videoconference meeting on the labour market held by the President in May 2020. At the meeting, the Minister of Labour, Anton Kotyakov, described the current situation on the labour market, and the Minister of Science and Higher Education, Valery Falkov, described measures to assist graduates of higher education institutions in finding employment. In addition, articles on the situation of the accountancy profession in the current reality were examined. For example, the accounting profession is still quite relevant today, but there is a trend towards broadening and deepening the knowledge of accountants, a modern candidate for the position of accountant must have certain competencies, a wide range of knowledge in the financial industry, be aware of trends in accounting and taxation, including in 
matters of rent accounting (Voronova, 2020). The study used general scientific methods: analysis, synthesis, systematization, induction and deduction.

\section{RESULTS AND DISCUSSION}

The restrictive measures imposed by the Government have necessitated adjustments in the way many companies operate. Retail shops and catering establishments were only open for delivery, shopping centres and offices were closed, and staff were mostly sent either to remote work or on forced leave (Zvereva, 2020). This, together with the depreciation of the rouble and the general economic crisis, brought about changes in the commercial real estate market. (Fig. 1)

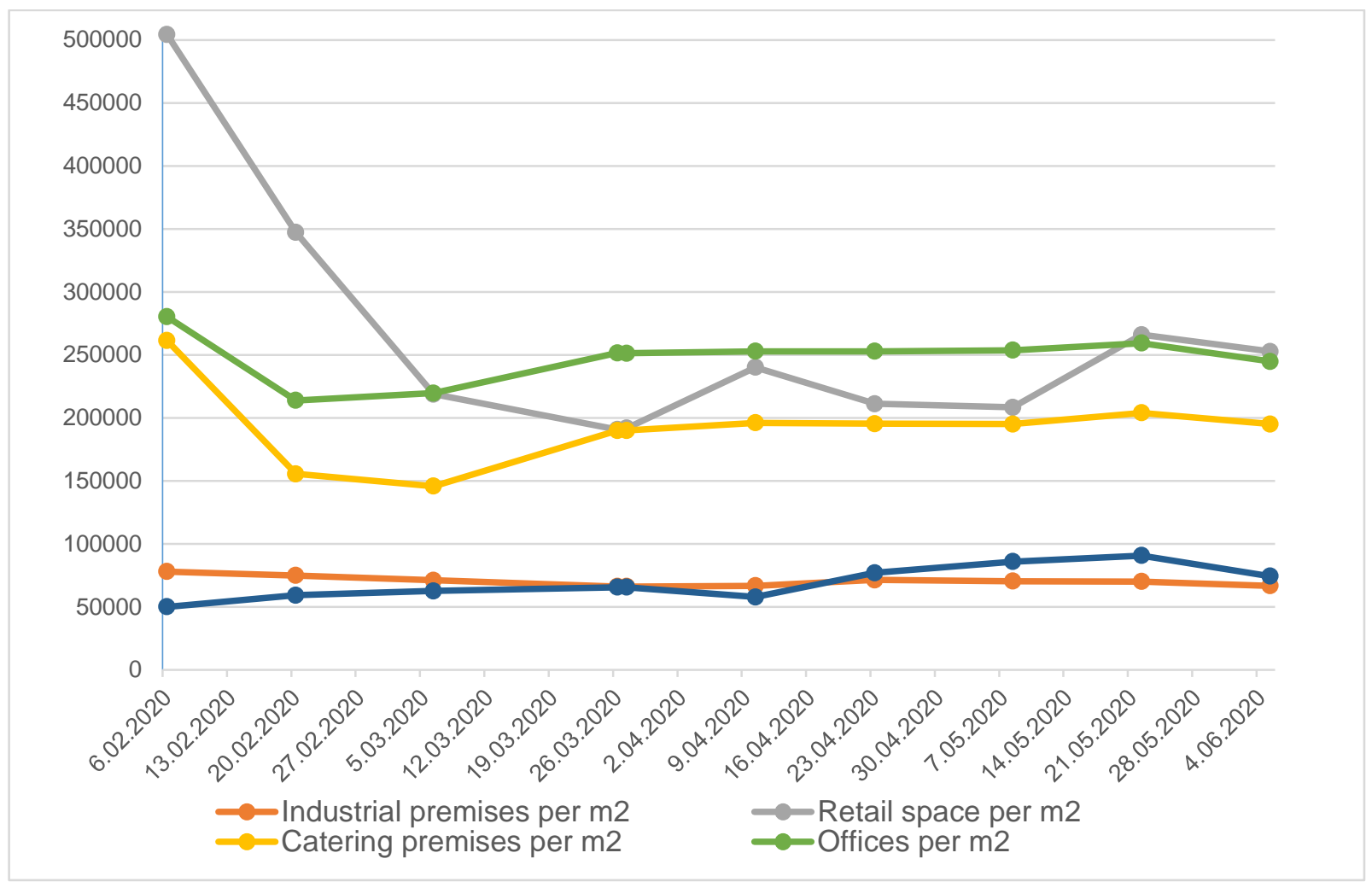

Fig. 1. The value of commercial real estate in Moscow for the period February-May 2020 (compiled by the author on the basis of https:/msk.restate.en/graphy/graphy-prodazhi-kommercheskoy)

As can be seen from the graph, commercial real estate in general has fallen sharply since February, with offices, commercial premises and catering facilities. In the case of warehouses, the price of this type of commercial real estate has increased slightly. This may be due to the fact that warehouses are actively used even during a pandemic, as traders operate on a limited basis. The cost of production facilities has changed little, probably because large factories and production of essential goods continue to operate in Moscow even during the quarantine period. The price decline is most pronounced in the Commercial Premises category, with the value at the beginning of June falling by almost $50 \%$ compared to the beginning of February. This is obviously due to the closure of all shopping malls and most non-food stores. Commercial premises, for example, include pharmacy networks located both in segregated rented buildings and in shopping malls. For example, the well-known pharmacy network «36.6» has announced the intention to close the outlets in Moscow shopping centers and look for new premises. This is due to the fact that some of the leases are in currency, which led to a rapid increase in the rental rate.

As described earlier, tenants had the opportunity to delay their rent payments during a period of difficult economic circumstances, against the backdrop of a pandemic. In order to obtain a delay, the tenant has to apply for a deferred rent. According to Federal Law of 01.04.2020 N 98-FL "On amendments to individual legislative acts of the English Federation on the prevention and elimination of emergency situations "The lessor is obliged to conclude, within 30 days, an additional agreement with the condition that the rent is deferred (art. 19, para. 1). Thus, there would be no automatic suspension without an application. A deferral could be requested until 1 October 2020, with the lease arrears to be paid no later than 1 January 2021 and no later than 1 January 2023. Payment will have to be effected in stages no more than once a month by 
equal payments, the amount of which shall not exceed 50 per cent of the monthly rent stipulated in the lease (sub-contract a, para. 3 of the Requirements). The organizations' accounting under the general taxation system would not reflect a delay in leasing: rental payments would be included in expenditure on a monthly basis as well. Companies under the Simplified Taxation System will not charge rent during the deferral period, lease costs will be written off only when cash is transferred to the counterparty at the end of the deferral. Organizations will only have an impact on the simplified tax system (without VAT) on the payment at the end of the deferral. For tenants, the accounting situation will be similar: under the common taxation system, tenants will charge payments on a monthly basis, on a simplified basis upon receipt of payment.

Thus, the obvious downside for the tenants' side is that not all can get the right to rent holidays. In practice, in addition to the industries on the official list of victims, many also suffer huge losses from the pandemic. For example, this includes the health sector, namely private clinics. To "officially injured» only such activity as rendering of dental services was attributed. According to TASS, in 2019 the volume of paid medicine amounted to more than 700 billion rubles. There are more than 500,000 people working in 30,000 organizations. However, this is not the case. Wages account for 60-65 per cent of earnings. Due to the pandemic, losses of 15 billion rubles per month are expected. [4]. It should also be noted that the lease can only be granted a grace period in the amount of the total rent provided for in the contract for the duration of the state of emergency. After completion, the lessee can expect to delay only half of the rent amount and until 1 October 2020 (sub-item b.3 Requirements). For real estate lessors, in turn, the deduction of income for the next six months is a negative factor from the provision of rental holidays. And even the easing of property tax and land tax does not absolve them of imminent losses. An attempt to evade or deny the tenants a stay may result in a lawsuit by the tenants and subsequent litigation. Under the circumstances, the court is likely to side with the tenants. The only way for lessors in this case is to study the benefits that can be granted by the regions, and in case of large losses - an attempt to terminate the lease contract prematurely due to a substantial change of circumstances (Civil Code of the English Federation, para.1.4.).

In addition to the possibility of a deferral, as mentioned earlier, the Federal Act 98-FL stipulates that the lessee may request a reduction in the rent for the period 2020 due to the impossibility of using the property (2, para 3 of 19). The lessee will not be entitled to a reduction in lease payments if its activities continue even in truncated form. For example, if a private dental clinic provided services and services to clients, even if only in urgent and critical cases, it is considered that it actually continued to operate. That is, it may be difficult in practice for a lessee to prove that the property he has leased is not being used. On the other hand, if the activities of the tenant are suspended by the authorities of the region during the pandemic, the lessor will have difficulty in contesting the lessee's inability to use the property. If the organization is still entitled to a reduction in rental payments, the accounting and tax records will reflect the rent under the existing rules but in a reduced amount.

Some sectors of the economy, such as restaurants, retail and pharmacy networks, have not been identified by the Government as being among the most affected, so the possibility of delay and reduction of rent payments are not eligible. In this connection, the owners of the major pharmacy chains have joined the declaration of good-faith cooperation on leases under the conditions of restrictions imposed by COVID-19. The Declaration states that many trade and service providers cannot operate in the same way as previously under restrictions. The parties to the declaration are not given adequate assistance from the State. Thus, for example, the Declaration was signed by the CEO of 19 pharmacy networks - «Rigla», «Neopharm», «Erkafarm», "Vita pharmacies», «Iris», «Nevis pharmacies», "Lecopttorg», "Health Springs», «Petersburg pharmacies», "Maksavita», from the trade networks joined the Declaration "Communication-Euronetwork», network «Republic» and others (Trade networks have joined the Rent Declaration).

The purpose of the declaration is to preserve business, jobs and the stability of contractual relations between tenants and lessors on terms acceptable to both parties. The declaration recommends that the parties adhere to a number of rules during the period of economic recovery during and after the restrictive measures. For example, do not occupy premises rented by organizations in a difficult economic situation for 360 days after the reopening of the facilities, do not collect rent or require payment for a period of time, during which the use of the space became impossible due to the imposed restrictions and to be guided by the "reasonable percentage» of the lessee's turnover when revising the lease rates under the contracts. Moreover, the participants in the declaration plan to agree on the establishment of an open list of unscrupulous practices by lessors and the public dissemination of any cases of abuse.

In the context of the business crisis of the pandemic, both tenant and tenant organizations are increasingly interested in having qualified accountants on their staff who are not only theoretical, but also deep practical knowledge in the field of accounting for rental operations. According to forecasts of the Russian Newspaper, starting from 2020 employers should noticeably increase the qualification requirements of accountants 
(Sharafutdinov, 2019). The reason for this is not only innovations in legislation related to the spread of the pandemic, but also the introduction on the territory of the Russian Federation of a number of new federal accounting standards, including FSBU 25/2018 «Lease». The new standards, according to the Genplace project development director Alexei Ivanov, are inherently more complex than existing standards and are in many ways similar to IFRS. According to him, in the present situation the professional judgment of the accountant will no longer be a mere theory (English Newspaper). For the moment, therefore, an important task for institutions of higher education is to train highly qualified accountants with the appropriate level of theoretical knowledge and practical experience, including in the area of rent accounting, since employed graduates with the necessary knowledge will be able to do much to help organizations cope with the impact of the current crisis.

During the «Government Hour» in the Federation Council on Labor Market Issues in May 2020, the head of the Ministry of Labor, Anton Kotyakov, reported on the high labor market tension coefficient. He noted that there were 18 applicants for 10 vacancies in Russia (Meeting on the Labor Market Situation). Recent data show that the number of officially registered unemployed in Russia is also growing against the background of the pandemic and the current crisis. Accordingly, the labor market is growing rapidly and competition among professionals, employers will again be interested in hiring a more qualified and experienced graduate. In $2020,554,000$ full-time students graduated from the country's universities. A number of them (estimated by experts at about 20 per cent) will continue with master's, postgraduate and residency programmers to enhance their knowledge and skills (Haykovskaya, 2020). According to preliminary estimates, 410,000 university graduates will enter the labor market this year, of whom 267,000 will graduate from full-time baccalaureate and specialized studies. Unlike masters, who tend to combine work and studies, bachelors enter the labor market for the first time and are most at risk of not finding work.

On the basis of the research carried out, it is clear that an important task for the Higher Education Institutions at the moment is to introduce qualitative changes in the Bachelor's Degree curriculum, including students studying in the field of accountancy, to improve their competitiveness in the ore market. (Turishcheva, 2020). In particular, such changes were needed in the area of leasing accounting, the improvement of theoretical knowledge in the recording of leases and the introduction of a practical-oriented approach based on the changes in Russian legislation. The practical approach to rent accounting plays an important role in the training of highly qualified professionals. This approach can be implemented through the involvement of wellknown and successful employers who can share their experience, the organization of scientific conferences and round tables to discuss problematic issues related to rent etc. (Golubtsova, 2019). The interaction of higher education institutions with employers is also an important aspect, through the identification in practice of problem areas in the recording of rents and the creation on that basis of subjects for students to write scientific articles, course papers and final qualification papers, that it will help students not only to gain practical knowledge, but also to acquire a range of competencies necessary for their professional activity as specialists in a dynamic economic environment.

\section{CONCLUSION}

Our study demonstrated that the Government's proposed lease support measures would only marginally reduce the losses of the organizations. It is worth noting that tenants will not be fully exempt from rent payments, which means that rent payments will still have to be paid. However, not all tenant organizations that suffer losses during periods of restrictive measures, such as the pharmacy network, which lost a third of the proceeds during the pandemic, can benefit from the relaxation. In this case, the lessees may attempt to negotiate directly with the lessor for a reduction in the rent, or for a deferral of payments, as the lessors find it difficult under the prevailing conditions to find new tenants and it is advantageous for the lease to continue. Second, as mentioned earlier, an attempt could be made to terminate the lease by reference to material changes in circumstances. In this case, however, it must be proved that the prevailing circumstances are not a business risk and that the parties to the contract could not foresee such a change of circumstances, and the limitations of a pandemic cannot be overcome. Under the current circumstances, both tenants and lessors suffer losses. Leaseholders are given the flexibility of deferring and reducing rent payments, but these measures can only partially help to keep them in check, as the deferral and reduction of rent payments do not completely eliminate them. Moreover, most organizations have not been able to obtain any support from the State, so they have to deal with difficulties themselves, as the trade and pharmacy networks mentioned in the case of the signatories of the declaration. Landlords, in turn, are forced to provide rent holidays and reduce payments, as if they refuse to do so awaits court proceedings or the loss of tenants.

Thus, in the current context of the economic crisis and the pandemic, there have been a number of significant changes in the accounting for rental transactions. These changes should be reflected in a change in the approach to training accounting professionals in the area of leasing. Institutions of higher education 
should be able to study in greater depth the theoretical basis of accounting for rental transactions for students, as well as apply a practical-oriented approach to teaching. As a basis for the entry into the labor market of high-quality specialists in their field, able to adapt to the dynamically changing economic conditions and to meet their tasks more efficiently and qualitatively.

\section{REFERENCE LIST}

Avvakumova, I.V., Bykanova, O.A. and Akhmadeev, R.G. (2020) Improvement of small business owners taxation. In the Proceedings of the 7th International Conference on Education and Social Sciences (INTCESS), p. 532-537

Bhaird, C.M. (2010) SME Financing: A Life Cycle Approach. In: Resourcing Small and Medium Sized Enterprises. Contributions to Management Science. Physica, Heidelberg. https://doi.org/10.1007/9783-7908-2399-8 2

Chaykovskaya, L.A., Turishcheva, T. B. and Akhmadeev R. G. (2020). Functional application of the internal control system in autonomous institutions. Bulletin of the National Academy of Sciences of the Republic of Kazakhstan, vol. 1 (383), p. 163 - 171.

Chun, G.H., Eppli, M.J. and Shilling, J.D. (2003) The Effect of Firm Characteristics on the Use of Percentage Retail Leases. The Journal of Real Estate Finance and Economics, vol. 27, p. $25-37$. https://doi.org/10.1023/A:1023655328856

Golubtsova, E.V. and Zvereva, A.O. (2019) Development of Tax Attractiveness of Russia's Special Administrative Areas with Fair Tax Competition. Proceedings of the 34th International Business Information Management Association Conference, IBIMA 2019: Education Excellence and Management of Innovations through Sustainable Economic Competitive Advantage Vision 2025, p. 2023- 2028.

Krahnen, J.P. and Meran, G. (1987) Why Leasing? An Introduction to Comparative Contractual Analysis. In: Bamberg G., Spremann K. (eds) Agency Theory, Information, and Incentives. Springer, Berlin, Heidelberg. https://doi.org/10.1007/978-3-642-75060-1_14

Martin, A., Markhvida, M. and Hallegatte, S. (2020) Socio-Economic Impacts of COVID-19 on Household Consumption and Poverty. EconDisCliCha. https://doi.org/10.1007/s41885-020-00070-3

Mayes, D.G. and Nicholas, C.S. (1988) Leasing and the Incentive to Invest. In: The Economic Impact of Leasing. Palgrave Macmillan, London. https://doi.org/10.1007/978-1-349-09523-0 5

Meeting on the Labor Market Situation (http://kremlin.ru/events/president/news/63419)

Morozova, T., Akhmadeev, R., Lehoux, L., Yumashev, A., Meshkova, G. and Lukiyanova, M. (2020). Crypto asset assessment models in financial reporting content typologies, Entrepreneurship and Sustainability Issues, vol.7(3), p. 2196-2212.

Peprníčková M. (2018) What Are the Origins of New Leasing Conceptual Models and How These Models Are Coming True in IFRS 16?. In: Procházka D. (eds) The Impact of Globalization on International Finance and Accounting. Springer Proceedings in Business and Economics. Springer, Cham. https://doi.org/10.1007/978-3-319-68762-9_31

Russian Newspaper: What will be with the most massive profession in Russia (https://rg.ru/2020/04/09/chtobudet_s--samojmassovojs--v-rossii.html)

Sharafutdinov, R., Gerasimov, V., Akhmetshin, E., Karasik, E. and Kalimullina, O. (2019). Inclusive development index in Russia: analysis, methods, possibility of application. Revista Genero \& Direito, vol. 8(4), p. 231-241.

Trade networks have joined the Rent Declaration (https:///www.kommersant.ru/doc/4323595)

Turishcheva, T., Akhmadeev, R., Bykanova, O. and Nastasyuk, N. (2020) Methodological Support for Internal Control of Autonomous Institutions. International Journal of Applied Exercise Physiology. vol. $9(4)$, p. $53-61$

Wang, J.G. and Yang, J. (2016) An Alternative Link Connecting Industry with Finance-Financial Leasing. In: Financing without Bank Loans. Springer, Singapore. https://doi.org/10.1007/978-981-10-0901-3 8 
Voronova, T. A., Golubtsova, E., V., Maksimov, D. A., Novikova, E. S. and Ponomareva, N., V. (2020) The Role of Taxation in the Competitiveness of Russian Education Following Globalization and Digitalization Processes in the World Economy. Turismo Estudos \& Práticas, vol.2, p. 1-7

Yoshida, J., Seko, M. \& Sumita, K. (2016) The Rent Term Premium for Cancellable Leases. The Journal of Real Estate Finance and Economics, vol. 52, p. 480-511. https://doi.org/10.1007/s11146-015-9528$\mathrm{X}$

Zhang, N. (2018) Leasing, legal environments, and growth: evidence from 76 countries. The Journal of Financial Economics, vol. 42, p. 746-764. https://doi.org/10.1007/s12197-017-9419-5

Zvereva, A.O., Golubtsova, E.V. and Tsilikova, M.S. (2020) The specifics of the use of tax instruments in the digital trade of the Russian Federation. In the Proceedings of the 7th International Conference on Education and Social Sciences (INTCESS), p. 44-50 